\title{
DEVELOPMENT OF THE RECIPE OF CORN STICKS BASED ON SUGAR CORN GRAIN AND DETERMINATION OF THEIR QUALITY PARAMETERS
}

\author{
Nadya Dzyuba \\ Department of restaurant and health food technology \\ Odessa National Academy of Food Technologies \\ 112 Kanatna str., Odessa, Ukraine, 65039 \\ figadya282@rambler.ru \\ Olena Bunyak \\ Odessa National Academy of Food Technologies \\ 112 Kanatna str., Odessa, Ukraine, 65039 \\ bunyak.e.v@gmail.com \\ Iryna Bilenka \\ Department of restaurant and health food technology \\ Odessa National Academy of Food Technologies \\ 112 Kanatna str., Odessa, Ukraine, 65039 \\ irinabelenka@gmail.com
}

\begin{abstract}
The recipes of extruded products, namely corn sticks "Kukurudzianka" and "Kukurudzianka+" based on sugar corn grain with the increased content of vitamins and protein were developed. The recipe of extruded grain products was optimized using an inset Excel Solver of a table processor MS Excel (WINDOWS 2010). The developed extrudates may be recommended for consumption by teenagers, children, at dietary nutrition, and consumption by other population layers.

Physical-chemical parameters of obtained extrudates were determined, the analysis of such parameters as soaking and digestion ability was conducted. The in vitro studies established that the developed products have a high level of assimilability, reaching almost $85 \%$.

The obtained data of studying quality parameters demonstrated that at storage during 6 months at temperature $(15 \pm 5)^{\circ} \mathrm{C}$ humidity $70-75 \%$ in the polypropylene package, the content of sanitary-demonstrative microorganisms corresponds to sanitary-hygienic requirements to dry breakfasts.

The developed products have the high content of protein substances that is important in the aspect of consuming need of the modern human's organism. Consumption of $100 \mathrm{~g}$ of sticks provides the human organism with irreplaceable amino acids in general by $24,1 \%$. The products, presented in the study differ by the high content of main nutrients, necessary for the human organism. The content of calcium satisfies almost $13 \%$ of the daily need, phosphorus $-75 \%$ and potassium - $9 \%$ at consumption of $100 \mathrm{~g}$ of corn sticks "Kukurudzianka" and "Kukurudzianka+".
\end{abstract}

Keywords: mathematical modeling of recipe, corn sticks, extruding.

\section{Introduction}

Nutrition is an important factor of the external environment that determines the proper development, health status and labor activity of a human. Nutrition must favor adaptation of the human organism to unfavorable conditions of the external environment. In this connection nutrition functions are not only in satisfying physiological needs of the organism in food substances and energy, and also in human health improvement, prevention of alimentary-depending diseases [1].

The special attention is paid to food products that correspond to modern quality and safety requirements, development of food products in the world and also technologies of products of the functional (treating and prophylactic) destination [1, 2].

Studies of nutritiologists testify to the fact that in modern society only traditional nutrition inevitably results in one or other forms of food insufficiency. Its causes are well-known - deficit of 
proteins, lack of vitamins and other macro- and micronutrients, consumption of refined food, wide use of diverse food additives that have no biological value [3].

The modern development stage of the human society is characterized by the abrupt worsening of the ecological situation in the world, permanent time deficit, changes of life rhythm and nutrition way. In this time human health is determined by two most important factors, such as nutrition and life style [3-5].

The intense human life rhythm in countries of Europe, USA, CIS resulted in a necessity to develop and make products of "fast food". They completely include dry breakfasts of the porous macrostructure as sticks, confectionary sticks, flakes, produced of grain, leguminous crops, potato and dried fruits. In the last ten years products ready to consumption, don't needing thermal processing, spread widely, the assortment of dry breakfasts was supplemented essentially, light grains, cushions with stuffing and so on appeared. The worldwide tendency to consumption of slowly assimilated carbohydrates dominates. Corn flakes and loosen (broken) grains became to be used as additives to soup instead of sippets, served to tea or coffee [3].

\section{Review of literary sources}

The process of extrusion of different biopolymers is widely used in the food-concentrate branch. It gives a possibility to process different types and mixtures of raw materials and to get in such a way products, unique by their food properties. Production of their wide spectrum is based mainly on the powerful industrial base of producers of extruders of different modifications and productivity, and also on the rigid control of raw materials, quality of obtained products and technological parameters of the process. As a result of extrusive processing of grain raw materials, there are observed different types of products, such as: ready breakfasts, snacks, spaghetti, fast cooked porridges, different textured products and so on $[4,5]$.

An important place among food concentrates is occupied by dry breakfasts, which cooking is based on such raw materials as different types of grain crops (wheat, rice, buckwheat, oats, barley and so on). As opposite to other food concentrates, dry breakfasts are not semi-products, but ones, ready to consumption, because they are produced by thermal processing $[6,7]$.

In this connection creation of the assortment of products of increased food value for correcting food rations of the population is an urgent task for today. In present time there are developed recipes and technologies of getting different types of grain products, widespread in mass nutrition of the population, namely, bakery and spaghetti products, food concentrates, enriched with different additives of both vegetable and animal origin [8]. There was conducted the analysis of corn sticks of different trademarks, presented in the distribution network of Ukraine, ones of Ukrainian companies and of producers of other countries of the world, namely: TM "Gold grain" by the Dnipro industrial complex of food concentrates, Ukraine; "Zabava” by "Beresteisky pekar" OJSC, Byelorussia; corn sticks by "Granex" CJSC, Lithuania; "Solnyskko" by Sojuzpischeprom LTD, Russia. The conducted analysis allowed to make a conclusion that these products are mostly unbalanced by the content of main food substances, contain an essential amount of easily assimilated carbohydrates, fats, food additives (dyers, aromatizers and so on).

There were developed the recipes of ready dry breakfasts with adding peeled grains, dry fruits and nuts for improving quality characteristics and food value of extrudates [9].

There was conducted the study about the influence of fenugreek flour (Trigonella foenum-graecum) and inclusion of fenugreek polysaccharide (FenuLife ${ }^{\circledR}$ ) on physical and sensor characteristics and glycemic index (GI) of extruded products, based on nut-rice. It has been proved, that $15 \%$ of fenugreek as desynthesized polysaccharide can be included to the mixture nut-rice for getting high sensor indices at the low GI value [10].

Work [11] presents the results of the development of compositional mixtures, based on extruded rice, wheat and corn grains, including processing products of fish industry wastes for producing porridges. It has been demonstrated, that introduction of the collagen preparation to projected recipes favors the biological value increase of culinary products and gives additional functional properties. 
An extruded snack product of maize is well-known [12]. It has the high level of acceptability for consumers comparing with commercially available extruded corn snacks. It also contained trice more protein and four times more food fibers.

There was studied the influence of replacement of native or extruded flour by 25 or $50 \%$ of proteins (collagen, milk, whey or egg white). Collagen was a single protein that raised water binding (to $233,72 \%$ ) for mixtures with native flour and to $40,85 \%$ for ones with extruded flour $[13,14]$

That is why the direction of developing extruded dry breakfasts, based on grain crops, including different types of natural additive of both vegetable and animal origin for creating products of the purpose-oriented effect with set food, biological and energetic value is topical. Widening of the assortment, making and consumption of enriched extruded grain products allow to decrease the protein insufficiency level, to enrich the population's food ration by necessary vitamins, macro- and microelements, food fibers and other biologically active substances that, in its turn, favor sanitation of the human organism.

The aim of the studies was to develop the composition of corn sticks with the balanced nutrient composition and improved consumption properties that allow to widen the assortment of functional products of the purpose-oriented effect.

\section{Materials and Methods}

The main raw material for producing corn sticks were: sugar corn (SS 6002), peeled barley (SSU 3769), carrot (SSU 7035:2009), licorice root (SSU 22839-88), collagen hydrolysate.

Optimization conditions of the recipe of corn sticks were presented as the complex of mathematical equations:

$$
\begin{gathered}
F=f\left(x_{1}, \ldots x_{i}, \ldots x_{n}\right) \rightarrow \text { const }, \quad i=\overline{1, n}, \\
x_{i} \leq(=, \geq) b_{i}, \quad i=\overline{1, n}, \quad d_{k} \leq x_{k} \leq D_{k}, \quad k=\overline{1, n},
\end{gathered}
$$

where $\mathrm{F}$ - target function of the linear model (maximal content of protein), $\mathrm{g} ; \mathrm{x}_{\mathrm{i}}$ - recipe component of the product, $\% ; b_{i}$ - limitation by the content of $i$-th element in the recipe, $\% ; x_{k}-k$ protein content in the recipe, $\% ; d_{k}, D_{k}-$ low and high limitation of $x_{k}$ protein content, $\% ; n-$ number of recipe components and nutrients.

The target function at mathematical construction of the recipes corresponded to the maximal protein content:

$$
\mathrm{Z}\left(\mathrm{x}_{\mathrm{i}}\right)=\max
$$

where $\mathrm{Z}\left(\mathrm{x}_{\mathrm{i}}\right)$ - target function that reflects the protein mass share in the recipe, $\mathrm{g} / 100 \mathrm{~g}$ of the ready product; $\mathrm{x}_{\mathrm{i}}$ - recipe component, $\mathrm{g} / 100 \mathrm{~g}$.

For modeling the recipe mathematically, there was used the method of linear problems, realized by the simplex-method $[15,16]$.

The used method of soaking determination is based on establishing the increase of the mass of products at immersion in water for some time (SS 5904-82). A soaking degree is characterized by the ratio of the product's mass after soaking to the mass of dry products and is expressed in per cents.

For determining the soaking, there is used a device, consisted of a three-section chamber. For conducting the experiment, the chamber is put in water, then put out, wiped by filtering paper from outside and weighed with an error no more than $0,01 \mathrm{~g}$. One whole corn stick is put in each section of the chamber, then the chamber with the products is weighed on scales with an error no more than $0,01 \mathrm{~g}$. The chamber is immersed in a container with water for I min, then it is put out and kept for 30 seconds in the inclined position for water excess flowing down. After that the chamber is wiped from outside and weighed with the soaked product. Soaking $(\mathrm{X})$ is calculated in per cents by the formula:

$$
\mathrm{X}=\frac{\mathrm{m}-\mathrm{m}_{1}}{\mathrm{~m}_{2}-\mathrm{m}_{1}} \cdot 100 \%,
$$


where $\mathrm{m}$ - mass of the chamber with the wet product, $\mathrm{g} ; \mathrm{m}_{1}$ - mass of the empty chamber (after immersion in water and removal of moisture from outside), $g ; \mathrm{m}_{2}-$ mass of the camber with the dry product, $\mathrm{g}$.

Determination of the digestion ability degree of the developed corn sticks. The digestion ability intensity was judged by the increment of the amount of final products of enzymatic hydrolysis of protein substances - free amino acids in the model medium. The studies were conducted by the following method.

A sample of the product is placed in the internal container of the device. Then it is added with $15 \mathrm{~cm}^{3}$ of the solution of hydrochloric acid with concentration $0,02 \mathrm{~mol} / \mathrm{dm}^{3}$ (pH 1,2). $60 \mathrm{~cm}^{3}$ of the same solution are poured in the external container for keeping isotony. The internal container is inserted in the external one in such a way that the low surface of its bottom is immersed in the solution at equality of liquid levels in temperature in the internal and external containers. The samples are incubated in the thermostate at $37^{\circ} \mathrm{C}$. After reaching the temperature balance in the whole system, $15 \mathrm{mg}$ of crystal pepsin are added to the internal container. The samples are taken out of the container each hour: $0,1 \mathrm{~cm}^{3}$ - from the internal one, $1 \mathrm{~cm}^{3}$ - from the external one. After that the volume of the hydrochloric acid solution $\left(0,02 \mathrm{~mol} / \mathrm{dm}^{3}\right)$, equal to the volume of the taken sample, is placed to the containers.

For stopping proteolysis and sedimentation of indigested protein, the sample from the internal container is dissolved in 10 times by the cooled solution of sodium tungstate with mass share $10 \%$. After centrifuging, hydrolysis products are determined by Lowry method.

The indices, obtained in the control samples: the first control - enzyme solution; the second control - suspension of the analyzed product in the buffer solution, are subtracted from the tyrosine concentration that characterizes the hydrolysis degree. The calculations are made by the formula:

$$
\mathrm{K}=\mathrm{A}-\mathrm{B}-\mathrm{C}
$$

where $\mathrm{K}$ - accumulation of hydrolysis products as a result of the effect of the proteolytic enzyme, $\mathrm{mcg} / \mathrm{cm}^{3} ; \mathrm{A}-$ concentration of hydrolysis products after digestion, $\mathrm{mcg} / \mathrm{cm}^{3} ; \mathrm{B}$ - concentration of the same products in suspension of the food product, $\mathrm{mcg} / \mathrm{cm}^{3} ; \mathrm{C}$ - concentration of the same products in the enzyme solution, $\mathrm{mcg} / \mathrm{cm}^{3}$.

\section{Experimental procedures}

The recipes of corn sticks, obtained using the inset Solver of the table processor MS Excel 2010 (WINDOWS 2010) are presented in Table 1.

At projecting the recipe of corn sticks, it was necessary to achieve the aim - the maximal value of the product with the following content of nutrients (in $100 \mathrm{~g}$ of the ready product): fats - no more than $12 \%$; monocarbohydrates - no more than $65 \%$ and no less than $50 \%$; dry substances - no more than $85 \%$ and no less than $96 \%$; proteins - no less than $20 \%$.

Table 1

Recipe composition of developed corn sticks

\begin{tabular}{ccc}
\hline \multirow{2}{*}{ Raw material } & \multicolumn{2}{c}{ Amount of raw material, $\mathbf{g}$} \\
\cline { 2 - 3 } & «Kukurudzianka» & «Kukurudzianka+» \\
\hline Peeled corn grains & 76,61 & 80,00 \\
Peeled barley grains & 15,00 & 20,00 \\
Licorice root & 1,83 & 1,00 \\
Blanched carrot & 4,58 & 5,00 \\
Collagen hydrolysate & 0 & 5,00
\end{tabular}

The indices of food, biological and energetic value were studied in developed corn sticks by conventional methods [17-19]. The energetic value of corn sticks is 179,53 and $208,49 \mathrm{kcal}$ 
in "Kukurudzianka" and "Kukurudzianked+" respectively. Based on the data about the chemical composition of corn sticks, it may be stated, that they have the essentially decreased content of fat and unessential amount of carbohydrates in their composition. Thus, the ratio of proteins:fats:carbohydrates for "Kukurudzianka" is 1:0,4:3,2, and for "Kukurudzianka+" - 1:0,5:3. The ratio of the main building materials calcium:magnesium:phosphorus for the developed corn sticks is almost 3:1:3,5. The low content of magnesium may be corrected, consuming this product with milk or yogurt, where the content is $14 \mathrm{mg}$ for $100 \mathrm{~g}$.

Due to the extruding process, there took place the partial hydrolysis of protein components of the raw material that essentially increased their ability to assimilation that is 85,2 and $83,5 \%$ for "Kukurudzianka" and "Kukurudzianked+" respectively. At that the biological value of the protein component for "Kukurudzianka" is 76,4 \%, and for "Kukurudzianked+"- 71,6 \%.

\section{Conclusions}

The recipes of extrudates were optimized using the table processor Solver (MS Excel 2010), the optimal content of all components was established. The content of protein in the developed corn sticks "Kukurudzianka" and "Kukurudzianked+" is 12,5 and 19,5 g/100 g respectively, that corresponds to the target function. Consumption of $100 \mathrm{~g}$ of the developed corn sticks provides the organism with irreplaceable amino acids by $24,1 \%$. The analysis of the chemical composition of the obtained products demonstrated their balance by main macronutrients.

The advantage of this study is the development of the recipe of extruded grain products (corn sticks) with the balanced composition and increased food value. The obtained corn sticks may be recommended for consumption by different population layers and also at dietary nutrition. The developed extrudates may be included in the food ration in sanitary institutions, for soldiers, schoolchildren, sportsmen and so on and also be realized through the distribution network. For introducing in production, it is planned to conduct SWOT - analysis of the developed corn sticks. In further it is planned to determine the complex quality parameter of corn sticks and calculation of their competitiveness.

\section{References}

[1] Advancing food safety initiatives: strategic plan for food safety including foodborne zoonoses 2013-2022 (2013). World Health Organization. Geneva, 32.

[2] Urubkov, S. A., Korolev, A. A., Koptyaeva, I. S., Korneva, L. Y. (2018). Development of dietary extruded products containing flax. Polzunovskiy vestnik, 4, 84-88. doi: http://doi.org/10.25712/ASTU.20728921.2018.04.017

[3] Kizatova, M. Zh., Iztaev, A. I., Abdykarimova, A. P., Nurgozhina, Zh. K. (2013). Znachenie ekstruzionnoy tekhnologii v proizvodstve pischevyh produktov. Vestnik Almatinskogo tekhnologicheskogo universiteta, 2, 58-62.

[4] Zimnyakov, V. M., Kukharev, O. N., Kurochkin, A. A., Frolov, D. I. (2017). Rational technological parameters in the production of multicomponent composite based on flax seeds. Niva Povolzh'ya, 4 (45), 157-163.

[5] Valevskaya, L., Dzyuba, N., Bunyak, E., Evdokimova, G. (2017). The meaning of grain cultures in healthy food. Sciences of Europe, 2 (18 (18)), 71-73.

[6] Iorhachova, K. H., Lebedenko, T. Ye. (2015). Khlibobulochni vyroby ozdorovchoho pryznachennia z vykorystanniam fitodobavok. Kyiv: K-pres, 464.

[7] Brownlee, I. A., Chater, P. I., Pearson, J. P., Wilcox, M. D. (2017). Dietary fibre and weight loss: Where are we now? Food Hydrocolloids, 68, 186-191. doi: https://doi.org/10.1016/j.foodhyd. 2016.08.029

[8] Kasyanov, G. I., Olkhovatov, E. A., Sakibaev, K. S. (2017). Innovations in the technology of dry breakfast products manufacturing. Nauchniy zhurnal KubGAU, 130 (06). doi: http://doi.org/10.21515/19904665-130-067

[9] Wani, S. A., Kumar, P. (2016). Effect of incorporation levels of oat and green pea flour on the properties of an extruded product and their optimization. Acta Alimentaria, 45 (1), 28-35. doi: https:// doi.org/10.1556/066.2016.45.1.4 
[10] Cardoso, J. de F., Casarotto Filho, N., Cauchick Miguel, P. A. (2015). Application of Quality Function Deployment for the development of an organic product. Food Quality and Preference, 40, 180-190. doi: https://doi.org/10.1016/j.foodqual.2014.09.012

[11] Telezhenko, L., Dzyuba, N., Kashkano, M. (2015). Instant porridge composition of the functional purpose: technological aspects. Food Science and Technology, 9 (4), 68-73

[12] Bravo-Núñez, Á., Gómez, M. (2019). Physicochemical properties of native and extruded maize flours in the presence of animal proteins. Journal of Food Engineering, 243, 49-56. doi: https://doi.org/10.1016/ j.jfoodeng.2018.09.005

[13] Telezhenko, L. M., Dzyuba, N. A., Kashkano, M. A., Valevska, L. O. (2016). Osnovy naukovykh doslidzhen. Kherson: Hrin D.S., 192.

[14] Jozinović, A., Šubarić, D., Ačkar, Đ., Babić, J., Miličević, B. (2016). Influence of spelt flour addition on properties of extruded products based on corn grits. Journal of Food Engineering, 172, 31-37. doi: https://doi.org/10.1016/j.jfoodeng.2015.04.012

[15] Mardar, M., Tkachenko, N., Znachek, R., Leonardi, C. (2017). Optimization of formulation composition of the crispbread with improved consumer properties. Technology Audit and Production Reserves, 2 (3 (34)), 22-29. doi: https://doi.org/10.15587/2312-8372.2017.99941

[16] Dzyuba, N., Telezhenko, L., Kashkano, M., Vikul, S., Priss, O., Zhukova, V. et. al. (2018). Development of recipes and estimation of the nutrient composition of cardio-protective fresh-mixes. EUREKA: Life Sciences, 1, 46-53. doi: https://doi.org/10.21303/2504-5695.2018.00548

[17] Belitz, H.-D. et. al. (2009). Food Chemistry. Springer-Verlag Berlin Heidelberg, 1070.

[18] Velisek, J. (2014). The Chemistry of Food. Wiley, 1125.

[19] Simpson, B. K. (Ed.) (2012). Food Biochemistry and Food Processing. Wiley, 900. doi: https:// doi.org/10.1002/9781118308035

\title{
INVESTIGATION OF TECHNOLOGICAL PROPERTIES OF FOUR-TYPE TRITICALE SEED OF DIFFERENT FRACTIONS
}

\author{
Vitalii Liubych \\ Department of seed storage and processing technology \\ Uman National University of gardening \\ 1 Institutska str., Uman, Ukraine, 20305 \\ LyubichV@gmail.com \\ Volodymyr Novikov \\ Department of seed storage and processing technology \\ Uman National University of gardening \\ 1 Institutska str., Uman, Ukraine, 20305 \\ 1990vovanovikov1990@gmail.com \\ Iryna Polianetska \\ Department of genetics, plants' selection and biotechnology \\ Uman National University of gardening \\ 1 Institutska str., Uman, Ukraine, 20305 \\ polyanetska@ukr.net \\ Serhiy Usyk \\ Department of general agriculture \\ Uman National University of gardening \\ 1 Institutska str., Uman, Ukraine, 20305 \\ sewooborot@gmail.com
}

